\title{
PROSEDUR PENETAPAN PENYEDIA BARANG DAN JASA SESUAI PEPRES NO. 54 TAHUN 2010 BESERTA PERUBAHANNYA MELALUI LPSE PADA UPT PSDA BAH BOLON PEMATANG SIANTAR
}

\author{
Firman Firdaus Pandiangan'1, Syahreza Alvan² \\ ${ }^{1}$ Alumni Program Studi D3 Teknik Sipil, Fakultas Teknik UNIMED \\ ${ }^{2}$ Dosen Pengajar Jurusan Pendidikan Teknik Bangunan, Fakultas Teknik UNIMED \\ (Syahrezalvan@gmail.com)
}

\begin{abstract}
ABSTRAK
Pengadaan barang dan jasa lebih dikenal dengan istilah pelelangan yang merupakan salah satu proses atau prosedur dari pemerintah untuk memberikan pekerjaan kepada pengusaha. Pengadaan barang dan jasa pemerintah dilakukan dengan proses pelelangan secara e-procurement sesuai dengan peraturan presiden No. 04 Tahun 2015 yang bertujuan untuk mempermudah para penyedia atau pengusaha dalam proses pelelangan di UPT PSDA Bah Bolon Pematang Siantar. Pada proses pelaksanaannya, dilaksanakan dengan meminimalkan pertemuan antara panitia dengan pihak penyedia jasa dengan tujuan agar terjadi persaingan sehat. Hal ini dapat dilihat pada keseluruhan proses pelelangan yang dilakukan secara elektronik yang dimulai dari pengumuman pelelangan, download dokumen pemilihan dan kualifikasi, penjelasan dokumen lelang (aanwijzing), upload dokumen penawaran (harga, administrasi dan teknis) serta dokumen kualifikasi, evaluasi penawaran, evaluasi dokumen kualifikasi dan pembuktian kualifikasi, upload berita acara hasil pelelangan, penetapan pemenang, pengumuman pemenang, masa sanggah hasil lelang, dan penandatanganan kontrak. Penulisan ini menyimpulkan bahwa terjadinya prosedur penetapan penyedia barang dan jasa yang terjadi di UPT PSDA Bah Bolon Pematang Siantar menggunakan lelang secara eprocurement dan proses pelelangannya sesuai dengan peraturan presiden No. 04 Tahun 2015.
\end{abstract}

Kata Kunci : E-procurement, Peraturan Presiden, Prosedur Penetapan Penyedia Barang/Jasa,

\begin{abstract}
Procurement of goods and services better known as the auction is one of the processes or procedures of the government to provide jobs to entrepreneurs. Government procurement of goods and services conducted by the auction process e-procurement in accordance with the presidential decree No. 04, 2015 which aims to make it easier for providers or employers in the bidding process in UPT NRM Bah Bolon Siantar. In the process of implementation, carried out by minimizing the meeting between the committee and the service provider in order to make healthy rivalry. This can be seen in the whole auction process is conducted electronically starting from the announcement of the auction, download the document selection and qualification, explanation of tender documents (aanwijzing), upload the document offers (prices, administrative and technical) and document the qualifications, evaluation of bids, evaluation document qualification and verification of qualifications, upload the minutes of the auction results, determining the winner, the winner announcement, auction results objection period, and the signing of the contract. This paper concludes that the determination procedures providers of goods and services which take place in UPT NRM Bah Bolon Siantar using e-procurement auction and the auction process in accordance with the presidential decree No. 04, 2015.
\end{abstract}

Keywords: Determination Procedure Goods / Services, E-procurement, Presidential Decree 


\section{Pendahuluan}

Dalam upaya mendapatkan pekerjaan penyedia barang (pengadaan) dan penyedia jasa konstruksi (proyek) hampir selalu melalui proses yang dinamakan pelelangan/tender. Proses ini menjadi sangat penting bagi pengusaha jasa konstruksi (kontraktor), karena kebutuhan hidupnya tergantung dari berhasilnya proses ini. Penetapan harga pelelangan/tender ditentukan oleh berbagai pertimbangan. Hal ini sangat menentukan besar/kecilnya keuntungan yang masih mungkin diperoleh kontraktor (pengusaha).

Pengadaan barang/jasa atau lebih dikenal dengan pelelangan merupakan salah satu proses atau prosedur dari pemerintah untuk memberikan pekerjaan kepada pengusaha (kontraktor). Pengadaan barang/jasa yang dilakukan dari pengadaan barang seperti pengadaan fasilitas kantor pada suatu instansi hingga pengadaan jasa seperti tenaga kerja pada suatu pekerjaan konstruksi.

Sistem pelelangan sesuai peraturan pemerintah yang dikelola oleh Lembaga Kebijakan Pengadaan Barang/Jasa Pemerintah (LKPP) saat ini menggunakan Layanan Pengadaan Secara Elektronik (LPSE). LPSE adalah suatu bentuk atau sistem baru dalam pengadaan barang/jasa yang mampu membantu pemerintah dalam hal transparansi informasi serta layanan masyarakat berbasis online web yang diterapkan oleh berbagai macam Peraturan Presiden (PEPRES) yang pada peraturan terakhirnya pada tahun 2015 .

Pada proses pelaksanaannya, dilaksanakan dengan meminimalkan pertemuan antara panitia dengan pihak penyedia jasa dengan tujuan agar terjadi persaingan sehat. Hal ini dapat dilihat pada keseluruhan proses pelelangan yang dilakukan secara elektronik yang dimulai dari pengumuman pelelangan, download dokumen pemilihan dan kualifikasi, penjelasan dokumen lelang (aanwijzing), upload dokumen penawaran (dokumen penawaran harga, administrasi dan teknis) serta dokumen kualifikasi, evaluasi penawaran, evaluasi dokumen kualifikasi dan pembuktian kualifikasi, upload berita acara hasil pelelangan, penetapan pemenang, pengumuman pemenang, masa sanggah hasil lelang, surat penunjukan penyedia barang/jasa dan penandatanganan kontrak.

Di sisi lain, dalam hal pengadaan barang/jasa pemerintah, pemerintah membutuhkan bantuan dan dukungan dari pihak lain baik itu dari BUMN ataupun dari perusahaan swasta. Hal ini dimaksudkan agar pengadaan barang/jasa pemerintah yang dibiayai dengan Anggaran Pendapatan dan Belanja Negara/Anggaran Pendapatan dan Belanja Daerah (APBN/APBD) dapat terlaksana dengan efektif dan efesien. Dalam melakukan pengadaan barang/jasa pemerintah, pemerintah memiliki prinsip persaingan sehat, transparan (terbuka), dan perlakuan yang adil bagi semua pihak.

Penyusunan jadwal pelaksanaan pengadaan perlu memberikan alokasi waktu yang cukup pada semua tahap proses pengadaan,terutama pada tahapan yang merupakan titik kritis seperti batas akhir pemasukan penawaran, pembukaan penawaran, pembuktian kualifikasi dan lainlainnya, sehingga memungkinkan informasi pengadaan dapat tersebar serta terjadinya persaingan secara adil antar penyedia barang/jasa.

\section{Kajian Teori}

\section{Pelelangan}

Setelah tahap desain diselesaikan oleh perencana, maka akan dilanjutkan dengan tahap pengadaan pelaksana konstruksi. Proses ini disebut procurement. Salah satu cara untuk mencari penyediaan jasa adalah dengan pelelangan atau tender. Pelelangan didefinisikan sebagai berikut :

Serangkaian kegiatan untuk menyediakan barang/jasa dengan cara menciptakan persaingan yang sehat di antara penyedia barang/jasa yang setara dan memenuhi syarat, berdasarkan metode dan tata cara tertentu yang telah ditetapkan dan diikuti oleh pihak-pihak yang terkait secara taat azas sehingga terpilih penyedia terbaik (Wulfram, 2009).

Proses pengadaan perusahan jasa konstruksi ini diatur oleh Keputusan Presiden terutama digunakan di lingkungan proyek pemerintah

\section{Pelelangan umum,}

adalah metoda pemilihan penyedia barang/jasa yang dilakukan secara terbuka dengan pengumuman secara luas melalui media massa dan papan pengumuman resmi untuk penerangan memenuhi kualifikasi dapat mengikutinya. 


\section{Prosedur Penetapan Penyedia Barang dan Jasa Sesuai Pepres No. 54 Tahun 2010 Beserta Perubahannya Melalui Lpse Pada Upt Psda Bah Bolon \\ Pematang Siantar}

Pelelangan terbatas,

Dapat dilaksanakan apabila dalam hal jumlah penyedia barang/jasa yang mampu melaksanakan diyakini terbatas, yaitu untuk pekerjaan yang kompleks, dengan cara mengumumkan secara luas melalui media massa dan papan pengumuman resmi dengan mencantumkan penyedia barang/jasa yang telah diyakini mampu, guna memberi kesempatan kepada penyedia barang/jasa lainnya yang memenuhi kualifikasi.

\section{Pemilihan Langsung,}

yaitu pengadaan barang/jasa tanpa melalui pelelangan dan hanya diikuti oleh penyedia barang/jasa yang memenuhi syarat. Pemilihan langsung dilakukan dengan cara membandingkan penawaran dan melakukan negoisasi, baik teknis maupun harga, sehingga diperoleh harga yang wajar dan secara teknis dapat dipertanggung jawabkan.

\section{Penunjukan Langsung,}

yaitu pelelangan barang/jasa dengan cara menunjuk langsung kepada satu penyedia jasa barang/jasa.

\section{Swakelola,}

yaitu pelaksanaan pekerjaan yang direncanakan, dikerjakan dan diawasi sendiri dengan menggunakan tenaga sendiri, alat sendiri, atau upah borongan tenaga. Dari keempat metode itu, hanya pelelangan yang akan kita bahas secara mendetail.

\section{Undang-undang Jasa Kontruksi}

Adapun undang-undang yang mengatur pelaksanaan tahapan tender di Indonesia sebagai berikut:

1) Undang-undang Republik Indonesia Nomor 18 Tahun 1999 Tentang Jasa Konstruksi, yang berbunyi sebagai berikut :

a. Dalam pembangunan nasional, jasa konstruksi mempunyai peranan penting dan strategi mengingat jasa konstruksi menghasilkan produk akhir berupa bangunan atau bentuk fisik lainnya, baik yang berupa prasarana maupun sarana yang berfungsi mendukung pertumbuhan dan perkembangan berbagai bidang, terutama bidang ekonomi, sosial, dan budaya untuk mewujudkan masyarakat adil dan makmur yang materiil dan spiritual berdasarkan Pancasila dan Undang-Undan Dasar 1945.

b. Jasa konstruksi nasional diharapkan semakin mampu mengembangkan perannya dalam pembangunan nasional melalui peningkatan keandalan yang didukung oleh struktur usaha yang kokoh dan mampu mewujudkan hasil pekerjaan yang berkualitas.

c. Dewasa ini, jasa konstruksi merupakan bidang usaha yang banyak dimintai oleh anggota masyarakat di berbagai tingkatan sebagaimana terlihat dari makin besarnya jumlah perusahaan yang bergerak di bidang usaha jasa konstruksi.

d. Sejalan dengan meningkatnya tuntutan masyarakat akan perluas cakupan, kualitas hasil maupun tertib pembangunan, telah membawa konsekuensi meningkatnya kompleksitas pekerjaan konstruksi tuntutan efesiensi, tertib penyelenggaraan, dan kualitas hasil pekerjaan konstruksi.

2) Peraturan Pemerintah Republik Indonesia Nomor 28 Tahun 2000

a. Undang-undang Nomor 18 tahun 1999 tentang jasa konstruksi telah mengatur landasan pokok dalam penyelenggaraan jasa konstruksi. Berdasarkan Undang-undang tersebut perlu diadakan peraturan pelaksanaan berupa Peraturan Pemerintah guna menindak lanjuti ketentuan-ketentuan yang diatur dalam Undang-Undang tersebut.

b. Dalam pasal 7 Undang-undang nomor 18 Tahun 1999 dinyatakan bahwa jenis usaha, bentuk usaha dan bidang usaha jasa konstruksi perlu diatur lebih oleh pemerintah.

c. Dalam pasal 10 Undang-undang tersebut dinyatakan pula bahwa Pemerintah harus mengatur tata cara penyelenggaran perizinan usaha, klasifikasi usaha, kualifikasi usaha, serta sertifikasi keterampilan dan sertifikat keahilan kerja jasa konstruksi.

3) Peraturan Presiden Republik Indonesia Nomor 70 Tahun 2012 Tentang Perubahan 
Kedua Atas Peraturan Presiden Nomor 54 Tahun 2010 Tentang Pengadaan Barang/Jasa Pemerintah

a. Pasal 4 ayat (1) Undang-Undang Dasar Negara Republik Indonesia Tahun 1945.

b. Undang-UndangNomor 1Tahun 2004 tentang Perbendaharaan Negara (Lembaran Negara Republik Indonesia Tahun 2004 Nomor 5, Tambahan Lembaran Negara Republik Indonesia Nomor 4355).

c. Peraturan Pemerintah Nomor 29 Tahun 2000 tentang Penyelenggaraan Jasa Konstruksi (Lembaran Negara Republik Indonesia Tahun 2000 Nomor 64, TambahanLembaran Negara Republik IndonesiaNomor 3956)sebagaimana telah diubah dengan Peraturan Pemerintah Nomor 59 Tahun 2010 (Lembaran Negara RepublikIndonesia Tahun 2010 Nomor 95).

d. Peraturan Presiden Nomor 54 Tahun 2010 tentang Pengadaan Barang/Jasa Pemerintah sebagaimana telah diubah dengan Peraturan Presiden Nomor 35 Tahun 2011 tentang Perubahan atas Peraturan Presiden Nomor 54 Tahun 2010 tentang Pengadaan Barang/Jasa Pemerintah.

4) Keputusan Menteri Pekerjaan Umum Nomor 223/Kpts/M/2011 Tentang Penetapan Organisasi Dan Pengurus Lembaga Pengembangan Jasa Konstuksi Nasional Periode 2011-2015

a. Bahwa sesuai dengan amanat Pasal 3 Peraturan Pemerintah Nomor 30 Tahun2000 tentang Penyelenggaraan Pembinaan Jasa Konstruksi, Pemerintahmelakukan pembinaan yang meliputi pengaturan, pemberdayaan dan pengawasan.

b. bahwa dalam rangka melaksanakan tugas pengaturan dan pemberdayaansebagaimana dimaksud dalam huruf a, Menteri Pekerjaan Umum perlumenetapkan dan menerbitkan organisasi dan susunan pengurus Lembaga Pengembangan Jasa Konstruksi.
PelelanganE-procurement
Pengumuman
Pemilihan
Penyedia

Barang/Jasa

a. ULP mengumumkan pelaksanaan Pengadaan Barang/Jasa secara luas kepada masyarakat pada saat:

1) Rencana kerja dan anggaran $K / L / D / I$ telah disetujui oleh DPR/DPRD

2) Daftar Isian Pelaksanaan Anggaran (DIPA)/Dokumen Pelaksanaan Anggaran (DPA) telahdisahkan.

b. Dalam hal ULP akan melakukan Pelelangan/Seleksi setelah rencana kerja dan anggaran $\mathrm{K} / \mathrm{L} / \mathrm{D} / \mathrm{I}$ disetujui DPR/DPRD tetapi DIPA/DPA belum disahkan, pengumuman dilakukan dengan mencantumkan kondisi DIPA/DPA belum disahkan.

c. Pelaksanaan Pelelangan/Seleksi diumumkan secara terbuka dengan mengumumkan secaraluas sekurangkurangnya melalui:

1) Website $K / L / D / I$

2) Papan pengumuman resmi untuk masyarakat

3) Portal Pengadaan Nasional melalui LPSE.

d. Pengumuman atas penetapan Penyedia Barang/Jasa diumumkan secara terbuka denganmengumumkan secara luas pada :

1) Website $K / L / D / I$

2) Papan pengumuman resmi untuk masyarakat

\section{Pendaftaran dan Pengambilan Dokumen}

a. Penyedia Barang/Jasa yang berminat mengikuti pemilihan Penyedia Barang/Jasa, mendaftaruntuk mengikuti Pelelangan/ Seleksi/Pemilihan Langsung kepada ULP.

b. Penyedia Barang/Jasa yang mengikuti Pengadaan Barang/Jasa melalui Penunjukan Langsung/Pengadaan Langsung diundang oleh ULP/Pejabat Pengadaan.

c. Penyedia Barang/Jasa mengambil Dokumen Pengadaan dari ULP/Pejabat Pengadaan ataumengunduh dari website yang digunakan oleh ULP.

\section{Pemberian Penjelasan}

a. Untuk memperjelas Dokumen Pengadaan Barang/Jasa, ULP/ Pejabat Pengadaan mengadakanpemberian penjelasan.

b. ULP/Pejabat Pengadaan dapat memberikan penjelasan lanjutan dengan cara melakukanpeninjauan lapangan. 


\section{Prosedur Penetapan Penyedia Barang dan Jasa Sesuai Pepres No. 54 Tahun 2010 Beserta Perubahannya Melalui Lpse Pada Upt Psda Bah Bolon Pematang Siantar}

c. Pemberian penjelasan harus dituangkan dalam Berita Acara Pemberian Penjelasan yangditandatangani oleh ULP/Pejabat Pengadaan dan minimal 1 (satu) wakil dari peserta yanghadir.

d. ULP memberikan salinan Berita Acara Pemberian Penjelasan dan Adendum DokumenPengadaan kepada seluruh peserta, baik yang menghadiri atau tidak menghadiri pemberianpenjelasan.

e. Apabila tidak ada peserta yang hadir atau yang bersedia menandatangani Berita AcaraPemberian Penjelasan, maka Berita Acara Pemberian Penjelasan cukup ditandatangani olehanggota ULP yang hadir.

f. Perubahan rancangan Kontrak dan/atau spesifikasi teknis dan/atau gambar dan/atau nilai totalHPS, harus mendapat persetujuan PPK sebelum dituangkan dalam Adendum DokumenPengadaan.

g. Dalam hal PPK tidak menyetujui usulan perubahan sebagaimana dimaksud maka :

1) ULP menyampaikan keberatan PPK kepada PA/KPA untuk diputuskan

2) Jika PA/KPA sependapat dengan PPK, tidak dilakukan perubahan

3) Jika PA/KPA sependapat dengan ULP, PA/KPA memutuskan perubahan dan bersifat final,serta memerintahkan ULP untuk membuat dan mengesahkan Adendum Dokumen

Pengadaan.

h. Ketidakhadiran peserta pada saat pemberian penjelasan tidak dapat dijadikan dasar untukmenolak/menggugurkan penawaran.

\section{Pemasukan Dokumen Penawaran}

a. Penyedia Barang/Jasa memasukkan Dokumen Penawaran dalam jangka waktu dan sesuaipersyaratan sebagaimana ditetapkan dalam Dokumen Pemilihan.

b. Dokumen Penawaran yang disampaikan melampaui batas akhir pemasukan penawaran tidakdapat diterima oleh ULP/Pejabat Pengadaan.

c. Penyedia Barang/Jasa dapat mengubah, menambah dan/atau mengganti Dokumen Penawaransebelum batas akhir pemasukan penawaran.

Evaluasi Penawaran

a. Dalam melakukan evaluasi penawaran, ULP/Pejabat Pengadaan harus berpedoman pada tatacara/kriteria yang ditetapkan dalam Dokumen Pengadaan.

b. Dalam evaluasi penawaran, ULP/Pejabat Pengadaan dan Penyedia Barang/Jasa dilarangmelakukan tindakan post bidding.

\section{Penetapan dan Pengumuman Pemenang}

a. ULP/Pejabat Pengadaan menetapkan hasil pemilihan Penyedia Barang/Jasa.

b. ULP/Pejabat Pengadaan mengumumkan hasil pemilihan Penyedia Barang/Jasa setelahditetapkan melalui website K/L/D/I dan papan pengumuman resmi.

\section{Sanggahan}

a. Peserta pemilihan Penyedia Barang/Jasa yang merasa dirugikan, baik secara sendiri maupunbersama-sama dengan peserta lainnya dapat mengajukan sanggahan secara tertulis apabilamenemukan:

1) Penyimpangan terhadap ketentuan dan prosedur yang diatur dalam Peraturan Presiden inidan yang telah ditetapkan dalam Dokumen Pengadaan Barang/Jasa.

2) Adanya rekayasa yang mengakibatkan terjadinya persaingan yang tidak sehat.

3) Adanya penyalahgunaan wewenang oleh ULP dan/atau Pejabat yang berwenang lainnya.

b. Surat sanggahan disampaikan kepada ULP dan ditembuskan kepada PPK, PA/KPA dan APIPK/L/D/I yang bersangkutan paling lambat 5 (lima) hari kerja setelah pengumuman pemenang.

c. ULP wajib memberikan jawaban tertulis atas semua sanggahan paling lambat 5 (lima) harikerja setelah surat sanggahan diterima.

d. Penyedia Barang/Jasa yang tidak puas dengan jawaban sanggahan dari ULP dapatmengajukan sanggahan banding kepada Menteri/Pimpinan Lembaga/Kepala Daerah/PimpinanInstitusi paling lambat 5 (lima) hari kerja setelah diterimanya jawaban sanggahan.

e. Penyedia Barang/Jasa yang mengajukan sanggahan banding wajib menyerahkan JaminanSanggahan Banding yang berlaku 20 (dua puluh) hari kerja sejak pengajuan SanggahanBanding.

f. Jaminan Sanggahan Banding ditetapkan sebesar 20/1000 (dua perseribu) dari nilai total HPSatau paling tinggi sebesar Rp50.000.000,00 (lima puluh juta rupiah). 
g. Sanggahan Banding menghentikan proses Pelelangan/Seleksi.

h. LKPP dapat memberikan saran, pendapat dan rekomendasi untuk penyelesaian sanggahanbanding atas permintaan Menteri/ Pimpinan Lembaga/Kepala Daerah/Pimpinan

Institusi.Menteri/Pimpinan

Lembaga/Kepala Daerah/Pimpinan Institusi memberikan jawaban atassemua sanggahan banding kepada penyanggah banding paling lambat 15 (lima belas) harikerja setelah surat sanggahan banding diterima.

i. Dalam hal sanggahan banding dinyatakan benar, Menteri/Pimpinan Lembaga/KepalaDaerah/Pimpinan Institusi memerintahkan ULP/Pejabat Pengadaan melakukan evaluasi ulangatau Pengadaan Barang/Jasa ulang.

j. Dalam hal sanggahan banding dinyatakan salah, Menteri/ Pimpinan Lembaga/KepalaDaerah/Pimpinan Institusi memerintahkan agar ULP melanjutkan proses PengadaanBarang/Jasa ulang.

k. Dalam hal sanggahan banding dinyatakan benar, Jaminan Sanggahan Banding dikembalikankepada penyanggah.

1. Dalam hal sanggahan banding dinyatakan salah, Jaminan Sanggahan Banding disita dan disetorkan ke kas Negara/Daerah.

\section{Pemilihan Gagal}

a. ULP menyatakan Pelelangan/Pemilihan Langsung gagal apabila :

1) Jumlah peserta yang lulus kualifikasi pada proses prakualifikasi kurang dari 3 (tiga) peserta.

2) Jumlah peserta yang memasukan Dokumen Penawaran untuk Pengadaan Barang/PekerjaanKonstruksi/Jasa Lainnya kurang dari 3 (tiga) peserta.

3) Sanggahan dari peserta terhadap hasil prakualifikasi ternyata benar.

4) Tidak ada penawaran yang lulus evaluasi penawaran.

5) Dalam evaluasi penawaran ditemukan bukti/indikasi terjadi persaingan tidak sehat.

6) harga penawaran terendah terkoreksi untuk Kontrak Harga Satuan dan Kontrak gabunganLump Sum dan Harga Satuan lebih tinggi dari HPS.

7) Seluruh harga penawaran yang masuk untuk Kontrak Lump Sum diatas HPS.
8) Sanggahan hasil Pelelangan dari peserta ternyata benar.

9) Calon pemenang dan calon pemenang cadangan 1 dan 2, setelah dilakukan evaluasi dengansengaja tidak hadir dalam klarifikasi dan/atau pembuktian kualifikasi.

b. ULP menyatakan Seleksi gagal apabila:

1) Peserta yang lulus kualifikasi pada proses prakualifikasi kurang dari 5 (lima) untuk Seleksi. Umum atau kurang dari 3 (tiga) untuk Seleksi Sederhana.

2) Sanggahan dari peserta terhadap hasil prakualifikasi dinyatakan benar

3) Tidak ada penawaran yang memenuhi persyaratan dalam evaluasi penawaran

4) Dalam evaluasi penawaran ditemukan bukti/indikasi terjadi persaingan tidak sehat.

5) Calon pemenang dan calon pemenang cadangan 1 dan 2 tidak hadir dalam klarifikasi dannegosiasi dengan alasan yang tidak dapat diterima

6) Tidak ada peserta yang menyetujui/menyepakati hasil negosiasi teknis dan harga.

7) Sanggahan hasil Seleksi dari peserta ternyata benar.

8) Penawaran biaya terendah terkoreksi untuk Kontrak Harga Satuan dan Kontrak gabunganLump Sum dan Harga Satuan lebih tinggi dari Pagu Anggaran.

9) Seluruh penawaran biaya yang masuk untuk Kontrak Lump Sum diatas Pagu Anggaran.

c. PA/KPA menyatakan Pelelangan/Seleksi/Pemilihan Langsung gagal apabila:

1) PA/KPA sependapat dengan PPK yang tidak bersedia menandatangani SPPBJ karenaproses Pelelangan/Seleksi/ Pemilihan Langsung tidak sesuai dengan Peraturan Presiden ini

2) Pengaduan masyarakat adanya dugaan KKN yang melibatkan ULP dan/atau PPK ternyata benar.

3) Dugaan KKN dan/atau pelanggaran persaingan sehat dalam pelaksanaanPelelangan/Seleksi/Pemilih an Langsung dinyatakan benar oleh pihak berwenang

4) Sanggahan dari Penyedia Barang/Jasa atas kesalahan prosedur yang tercantum 


\section{Prosedur Penetapan Penyedia Barang dan Jasa Sesuai Pepres No. 54 Tahun 2010 Beserta Perubahannya Melalui Lpse Pada Upt Psda Bah Bolon \\ Pematang Siantar}

dalamDokumen Pengadaan Penyedia Barang/Jasa ternyata benar.

5) Dokumen Pengadaan tidak sesuai dengan Peraturan Presiden ini.

6) Pelaksanaan

Pelelangan/Seleksi/Pemilihan Langsung tidak sesuai atau menyimpang dariDokumen Pengadaan.

7) Calon pemenang dan calon pemenang cadangan 1 dan 2 mengundurkan diri.

8) Pelaksanaan

Pelelangan/Seleksi/Pemilihan Langsung melanggar Peraturan Presiden ini.

d. PA/KPA/PPK/ULP dilarang memberikan ganti rugi kepada peserta Pelelangan/Seleksi/Pemilihan Langsung bila penawarannya ditolak atau Pelelangan/Seleksi/Pemilihan

Langsungdinyatakan gagal.

e. Menteri/Pimpinan Lembaga/Pimpinan Institusi menyatakan Pelelangan/Seleksi/ PemilihanLangsung gagal apabila:

1) Sanggahan banding dari peserta ternyata benar.

2) Pengaduan masyarakat adanya dugaan KKN yang melibatkan KPA ternyata benar.

f. Kepala Daerah menyatakan Pelelangan/Seleksi/Pemilihan Langsung gagal apabila:

1) Sanggahan banding dari peserta ternyata benar.

2) Pengaduan masyarakat adanya dugaan KKN yang melibatkan PA dan/atau KPA ternyatabenar.

g. Dalam hal Pelelangan/Seleksi/Pemilihan Langsung dinyatakan gagal, maka ULP segeramelakukan:

1) Evaluasi ulang

2) Penyampaian ulang Dokumen Penawaran.

3) Pelelangan/Seleksi/Pemilihan Langsung ulang

4) Penghentian

proses

Pelelangan/Seleksi/Pemilihan

Langsung.

h. Dalam hal Pelelangan/Seleksi ulang jumlah Penyedia Barang/Jasa yang lulus prakualifikasihanya 2 (dua) peserta, proses Pelelangan/Seleksi dilanjutkan.

i. Dalam hal Pelelangan/Seleksi/Pemilihan Langsung ulang jumlah Penyedia Barang/ Jasa yangmemasukkan penawaran hanya 2 (dua) peserta, proses Pelelangan/ Seleksi/PemilihanLangsung dilanjutkan.

j. Dalam hal Pelelangan/Seleksi ulang jumlah Penyedia Barang/ Jasa yang lulus prakualifikasihanya 1 (satu) peserta, Pelelangan/ Seleksi ulang dilakukan seperti proses PenunjukanLangsung.

k. Dalam hal Pelelangan/Seleksi/Pemilihan Langsung ulang jumlah Penyedia Barang/ Jasa yangmemasukkan penawaran hanya 1 (satu) peserta, Pelelangan/Seleksi/ Pemilihan Langsungulang dilakukan seperti halnya proses Penunjukan Langsung.

\section{Penandatanganan Kontrak Pengadaan Barang/Jasa}

a. PPK menyempurnakan rancangan Kontrak Pengadaan Barang/ Jasa untuk ditandatangani.

b. Penandatanganan Kontrak Pengadaan Barang/Jasa dilakukan setelah DIPA/DPA disahkan.

c. Para pihak menandatangani Kontrak setelah Penyedia Barang/ Jasa menyerahkan JaminanPelaksanaan paling lambat 14 (empat belas) hari kerja terhitung sejak diterbitkannya SPPBJ.

d. Penandatanganan Kontrak Pengadaan Barang/Jasa yang kompleks dan/atau bernilai diatasRp100.000.000.000,00 (seratus miliar rupiah) dilakukan setelah memperoleh pendapat ahlihukum Kontrak.

e. Pihak yang berwenang menandatangani Kontrak Pengadaan Barang/Jasa atas nama PenyediaBarang/Jasa adalah Direksi yang disebutkan namanya dalam Akta Pendirian/Anggaran DasarPenyedia Barang/Jasa, yang telah didaftarkan sesuai dengan peraturan perundang-undangan.

f. Pihak lain yang bukan Direksi atau yang namanya tidak disebutkan dalam AktaPendirian/Anggaran Dasar sebagaimana dimaksud, dapat menandatanganiKontrak Pengadaan Barang/Jasa, sepanjang mendapat kuasa/ pendelegasian wewenang yangsah dari Direksi atau pihak yang sah berdasarkan Akta Pendirian/Anggaran Dasar untukmenandatangani Kontrak Pengadaan Barang/Jasa.

3. Pelaksanaan Tender

3.1 Lokasi Penelitian

Penelitian ini dilakukan di Kantor UPT PSDA Bah Bolon Dinas PSDA Provinsi 
Sumatera Utara Jalan Asahan Km. 3,5 Pematang Siantar.

\subsection{Prosedur Penetapan Penyedia Barang dan} Jasa Pengumuman Pascakualifikasi

Pengumuman pada lelang secara $e$ procurement selain dilaksanakan melalui papan pengumuman pada instansi pelaksana pengadaan juga dilaksanakan pada portal pengadaan nasional melalui LPSE. Dengan perkembangan teknologi dan informasi, maka pengumuman pelelangan yang dilakukan pada hari ini, pada jam yang sama sudah tersebar di dunia maya dan dapat diakses oleh peserta dan panitia. Dengan adanya portal pengadaan nasional, yang bisa diakses melalui http://inaproc.lkpp.go.id, maka pengumuman pelelangan seluruh Indonesia dapat diakses hanya dari 1 portal tanpa harus mencari satu-persatu melalui lebih dari 500 LPSE di Seluruh Indonesia.

\section{Pendaftaran dan Pengambilan Dokumen}

Sistem e-procurement, pendaftaran dilakukan secara online saja. Dari sisi panitia tidak melakukan apa-apa, cukup melihat layar monitor sekali-sekali untuk mengecek jumlah pendaftar, dan dari sisi peserta cukup login menggunakan username dan password yang telah dimiliki, membaca pengumuman lelang dan syarat-syaratnya, kemudian mengklik tombol daftar pada lelang tersebut. Dengan mengklik tombol daftar, maka secara otomatis sudah dilakukan penandatanganan Pakta Integritas juga. Jadi tidak perlu meja pendaftaran, tidak perlu fotokopi SIUP, tidak perlu datang jauh-jauh ke kantor pelaksana lelang, dan cukup dilakukan dari kantor penyedia. Untuk pengambilan dokumen diunduh dari website yang sudah kita daftar.

\section{Penjelasan Dokumen dan Perubahan Dokumen}

Dengan sistem e-procurement, tidak dilakukan tatap muka pada tahapan ini. Masing-masing pihak cukup berada di depan komputer mereka. Penjelasan, pertanyaan dan jawaban dilakukan secara online. Panitia dan seluruh pendaftar pada lelang tersebut bisa saling bertukar penjelasan, pertanyaan, dan jawaban. Dengan cara seperti ini, tidak ada kontak fisik yang terjadi.Tanya jawab dilakukan sampai batas waktu aanwijzing selesai. Apabila jadwalnya telah selesai, maka secara otomatis penyedia tidak bisa mengirimkan pertanyaan lagi, namun panitia masih punya waktu minimal 1 jam untuk menjawab pertanyaan-pertanyaan yang diajukan pada akhir waktu.

Upload Dokumen Penawaran dan Pembukaan Dokumen Penawaran

Untuk upload dokumen penawaran eprocurement, maka penyedia tidak perlu repot-repot menyiapkan dana untuk fotokopi semua dokumen pendukung kualifikasi serta dokumen administrasi maupun teknis. Penyedia langsung saja meng-upload dokumen penawaran beserta dokumen teknis yang sudah selesai dikerjakan kedalam system elektronik melalui LPSE. Kemudian panitia tinggal membuka semua penawaran yang masuk.

\section{Evaluasi Penawaran}

Dalam evaluasi penawaran, panitia khusus memeriksa kelengkapan penawaran yang masuk dari beberapa penyedia.

\section{Evaluasi dan Pembuktian Dokumen Kualifikasi (Lelang)}

Panitia memeriksa semua kelengkapan yang ada dari calon pemenang dan juga memeriksa keaslian dokumen, Karena dalam evaluasi Kualifikasi, penyedia harus menunjukan dokumen-dokumen asli kepada panitia dan pembuktian kualifikasi dilakukan secara offline. Apabila hasil pembuktian kualifikasi ditemukan pemalsuan data, peserta digugurkan, badan usaha atau peserta perorangan dimasukkan dalam Daftar Hitam, serta dilaporkan kepada Kepolisian atas perbuatan pemalsuan tersebut. Apabila tidak ada penawaran yang lulus pembuktian kualifikasi, pelelangan dinyatakan gagal.

\section{Upload Berita Acara Hasil Pelelangan}

Panitia membuat dan menandatangani Berita Acara Hasil Pelelangan (BAHP) yang paling sedikit memuat:

a. Nama seluruh peserta; 


\section{Prosedur Penetapan Penyedia Barang dan Jasa Sesuai Pepres No. 54 Tahun 2010 Beserta Perubahannya Melalui Lpse Pada Upt Psda Bah Bolon \\ Pematang Siantar}

b. Harga penawaran atau harga penawaran terkoreksi dari masingmasing peserta;

c. Metode evaluasi yang digunakan;

d. Unsur-unsur yang dievaluasi;

e. Rumus yang dipergunakan;

f. Keterangan-keterangan lain yang dianggap perlu hal ikhwal pelaksanaan pelelangan;

g. Jumlah peserta yang lulus dan tidak lulus pada setiap tahapan evaluasi dan tanggal dibuatnya Berita Acara.

\section{Penetapan dan Pengumuman Pemenang}

Pokja ULP melakukan penetapan pemenang melalui aplikasi SPSE setelah melalui pembahasan internal anggota Pokja ULP, atau setelah ditetapkan PA secara offline untuk nilai paket di atas Rp100.000.000.000,00 (seratus miliar rupiah). Pokja ULP dapat menetapkan pemenang lebih dari 1 (satu) penyedia sesuai ketentuan yang terdapat dalam pada informasi paket dalam aplikasi SPSE. Apabila terjadi keterlambatan dalam menetapkan pemenang dan akan mengakibatkan Surat Penawaran habis masa berlakunya, maka dilakukan konfirmasi kepada calon pemenang, calon pemenang cadangan 1 dan 2 (apabila ada) untuk memperpanjang masa berlaku surat penawaran secara tertulis sampai dengan perkiraan jadwal penandatanganan kontrak. Calon pemenang, calon pemenang cadangan 1 dan 2 (apabila ada) yang tidak bersedia memperpanjang masa berlaku surat penawaran dianggap mengundurkan diri dan tidak dikenakan sanksi. Pokja ULP mengumumkan pemenang dan pemenang cadangan 1 dan 2 (apabila ada) melalui aplikasi SPSE, di website sebagaimana tercantum dalam LDP.

\section{Sanggah Hasil Lelang}

Peserta yang memasukkan penawaran dapat menyampaikan sanggahan secara elektronik melalui aplikasi SPSE atas penetapan pemenang kepada Pokja ULP dalam waktu yang telah ditetapkan dengan disertai bukti terjadinya penyimpangan dan dapat ditembuskan secara offline (di luar aplikasi SPSE) kepada KPA, PA/KPA dan APIP sebagaimana tercantum dalam LDP. Sanggahan diajukan oleh peserta apabila terjadi penyimpangan prosedur meliputi:

a. Penyimpangan terhadap ketentuan dan prosedur yang diatur dalam Peraturan Presiden No. 54 Tahun 2010 tentang Pengadaan Barang/Jasa Pemerintah beserta perubahan dan aturan turunannya serta yang telah ditetapkan dalam Dokumen Pengadaan;

b. Rekayasa tertentu sehingga menghalangi terjadinya persaingan usaha yang sehat; dan/atau

c. Penyalahgunaan wewenang oleh Pokja ULP dan/atau pejabat yang berwenang lainnya.

Pokja ULP wajib memberikan jawaban secara elektronik atas semua sanggahan paling lambat 3 (tiga) hari kalender setelah menerima sanggahan. Apabila sanggahan dinyatakan benar maka Pokja ULP menyatakan pelelangan gagal.

Sanggahan dianggap sebagai pengaduan, dalam hal:

a) Sanggahan disampaikan tidak melalui aplikasi SPSE (offline), kecuali keadaan kahar atau gangguan teknis;

b) Sanggahan ditujukan kepada bukan kepada Pokja ULP; atau

c) Sanggahan disampaikan diluar masa sanggah.

Sanggahan yang dianggap sebagai pengaduan tetap harus ditindak lanjuti.

\section{Surat Penunjukan Penyedia Barang/Jasa (SPPBJ)}

Pokja ULP menyampaikan Berita Acara Hasil Pelelangan (BAHP) kepada KPA dengan tembusan kepada Kepala ULP sebagai dasar untuk menerbitkan Surat Penunjukan Penyedia Barang/Jasa (SPPBJ). KPA menerbitkan SPPBJ apabila pernyataan peserta pada formulir isian kualifikasi masih berlaku, dengan ketentuan:

a. Tidak ada sanggahan dari peserta;

b. Sanggahan terbukti tidak benar; atau

c. Masa sanggah berakhir.

KPA menginputkan data SPPBJ dan mengunggah hasil pemindaian SPPBJ yang telah diterbitkan pada aplikasi SPSE dan mengirimkan SPPBJ tersebut melalui aplikasi SPSE kepada Penyedia yang ditunjuk. Penyedia yang ditunjuk wajib 
menerima keputusan tersebut, dengan ketentuan:

a. Apabila yang bersangkutan mengundurkan diri dengan alasan yang dapat diterima secara obyektif oleh Pokja ULP dan masa penawarannya masih berlaku, yang bersangkutan tidak dikenakan sanksi;

b. Apabila yang bersangkutan mengundurkan diri dengan alasan yang tidak dapat diterima secara obyektif oleh Pokja ULP dan masa penawarannya masih berlaku, maka yang bersangkutan dimasukkan dalam Daftar Hitam; atau

c. Apabila yang bersangkutan tidak bersedia ditunjuk karena masa penawarannya sudah tidak berlaku, maka peserta yang bersangkutan tidak dikenakan sanksi.

Apabila pemenang yang ditunjuk mengundurkan diri, maka penunjukan pemenang dapat dilakukan kepada pemenang cadangan sesuai dengan urutan peringkat, selama masa surat penawaran pemenang cadangan masih berlaku atau sudah diperpanjang masa berlakunya.

Apabila semua pemenang yang ditunjuk mengundurkan diri, maka pelelangan dinyatakan gagal oleh PA/KPA setelah mendapat laporan dari KPA. SPPBJ harus diterbitkan paling lambat 4 (empat) hari kerja setelah pengumuman penetapan pemenang, apabila tidak ada sanggahan atau 2 (dua) hari kerja setelah semua sanggahan dijawab.

\section{Penandatanganan Kontrak}

Setelah SPPBJ diterbitkan, KPA melakukan finalisasi terhadap rancangan Kontrak, dan menandatangani Kontrak pelaksanaan pekerjaan, apabila dananya telah cukup tersedia dalam dokumen anggaran, dengan ketentuan sebagai berikut:

a. Sebelum penandatanganan kontrak KPA wajib memeriksa apakah pernyataan dalam Formulir Isian Kualifikasi masih berlaku. Apabila salah satu pernyataan tersebut tidak terpenuhi, maka penandatanganan kontrak tidak dapat dilakukan. b. Penandatanganan kontrak dilakukan setelah Penyedia menyerahkan Jaminan Pelaksanaan, dengan ketentuan:

1. nilai Jaminan Pelaksanaan untuk harga penawaran atau penawaran terkoreksi diatas $80 \%$ (delapan puluh perseratus) nilai total HPS adalah sebesar 5\% (lima perseratus) dari nilai penawaran atau penawaran terkoreksi; atau

2. nilai Jaminan Pelaksanaan untuk harga penawaran atau penawaran terkoreksi dibawah $80 \%$ (delapan puluh perseratus) nilai total HPS adalah sebesar 5\% (lima perseratus) dari nilai total HPS;

c. KPA dan penyedia tidak diperkenankan mengubah substansi Dokumen Pengadaan sampai dengan penandatanganan Kontrak, kecuali mempersingkat waktu pelaksanaan pekerjaan dikarenakan jadwal pelaksanaan pekerjaan yang ditetapkan sebelumnya akan melewati batas tahun anggaran.

d. Dalam hal kontrak tahun tunggal perubahan waktu pelaksanaan pekerjaan melewati batas tahun anggaran, penandatanganan kontrak dilakukan setelah mendapat persetujuan kontrak tahun jamak.

e. KPA dan Penyedia wajib memeriksa konsep Kontrak meliputi substansi, bahasa, redaksional, angka dan huruf serta membubuhkan paraf pada setiap lembar Dokumen Kontrak.

f. Menetapkan urutan hirarki bagianbagian Dokumen Kontrak dalam Surat Perjanjian, dengan maksud apabila terjadi pertentangan ketentuan antara bagian satu dengan bagian yang lain, maka berlaku urutan sebagai berikut:

1. adendum Surat Perjanjian;

2. pokok perjanjian, syarat-syarat khusus kontrak, syarat-syarat umum kontrak;

3. surat penawaran, beserta penawaran harga;

4. spesifikasi teknis;

5. gambar-gambar;

6. daftar kuantitas (apabila ada); dan

7. dokumen lainnya seperti: jaminanjaminan, SPPBJ, BAHP.

g. Banyaknya rangkap kontrak dibuat sesuai kebutuhan, yaitu: 


\section{Prosedur Penetapan Penyedia Barang dan Jasa Sesuai Pepres No. 54 Tahun 2010 Beserta Perubahannya Melalui Lpse Pada Upt Psda Bah Bolon \\ Pematang Siantar}

1. sekurang-kurangnya 2 (dua) Kontrak asli, terdiri dari:

a) kontrak asli pertama untuk KPA dibubuhi materai pada bagian yang ditandatangani oleh penyedia; dan

b) kontrak asli kedua untuk penyedia dibubuhi materai pada bagian yang ditandatangani oleh KPA;

2. rangkap kontrak lainnya tanpa dibubuhi materai, apabila diperlukan.

h. Pihak yang berwenang menandatangani kontrak atas nama penyedia adalah direktur utama/pimpinan perusahaan/pengurus koperasi yang disebutkan namanya dalam Akta Pendirian/ Anggaran Dasar, yang telah didaftarkan sesuai dengan peraturan perundang-undangan.

i. Pihak lain yang bukan direktur utama/pimpinan perusahaan/pengurus koperasi atau yang namanya tidak disebutkan dalam Akta Pendirian/Anggaran Dasar, dapat menandatangani Kontrak, sepanjang pihak tersebut adalah pengurus/karyawan perusahaan/karyawan koperasi yang berstatus sebagai tenaga kerja tetap dan mendapat kuasa atau pendelegasian wewenang yang sah dari direktur utama/pimpinan perusahaan/ pengurus atau pihak yang sah berdasarkan Akta Pendirian/Anggaran Dasar untuk menandatangani Kontrak.

j. KPA menginputkan data kontrak dan mengunggah hasil pemindaian dokumen kontrak yang telah ditandatangani pada aplikasi SPSE.

\section{Kesimpulan dan Saran}

\subsection{Kesimpulan}

Adapun kesimpulan-kesimpulan yang dapat diambil dari penulisan Tugas Akhir ini adalah :

1. Saat ini dalam lelang peranan internet terasa sangat penting. Hal tersebut terlihat dari merebaknya jumlah dan jenis pelelang yang ada di internet. Dengan internet, para pelaku lelang dapat melakukan proses lelangnya secara cepat di mana pun ia berada. Proses lelang secara manual dinilai tidak efisien karena proses ini memerlukan tatap muka secara langsung. Para pelaku lelang yang menggunakan proses lelang secara langsung akan mengalami kesulitan baik dari segi waktu ataupun jarak. Prosedur pelelangan atau penetapan penyedia barang/jasa pada UPT PSDA Bah Bolon Pematang Siantar melakukan pelelangan secara eprocurement dari pascakualifikasi hingga pengumuman pemenang dilakukan secara online sesuai dengan peraturan presiden. Pengumuman pada lelang secara e-procurement selain dilaksanakan secara online pada portal LPSE, juga diumumkan pada papan pengumuman di kantor UPT PSDA.

2. Proses terjadinya perubahan peraturan melalui LPSE terjadi 4 kali perubahan sejak tahun 2010 hingga 2015. Perubahan pertama pada tahun 2011 merubah sebanyak 1 pasal saja. Perubahan kedua pada tahun 2012 merubah sebanyak 60 pasal. Pada perubahan ketiga tahun 2014 Peraturan Presiden hanya merubah 1 pasal saja, dan perubahan terakhir di tahun 2015 merubah sebanyak 18 pasal.

\subsection{Saran}

Beberapa hal yang dapat penulis sampaikan sebagai saran pada saat penyusunan laporan Tugas Akhir ini ialah sebagai berikut :

1. Sebaiknya pada saat lelang secara eprocurement dilakukan juga pemeriksaan data asli secara online. Karena terjadi kesulitan pada saat pembuktian kualifikasi data pelelangan, dimana para penyedia harus menunjukan dokumen-dokumen asli kepada Pokja ULP secara offline yang dapat mengeluarkan biaya operasional tambahan dari segi waktu dan materi.

2. Bila terjadi perubahan peraturan presiden, sebaiknya ada sosialisasi atau pemberitahuan kepada penyedia melalui e-mail dari masing-masing penyedia agar tidak terjadi hambatan diantara jalannya proses pelelangan dengan peraturan yang berlaku.

\section{Daftar Pustaka}

Ervianto. Wulfram I. 2009. Manajemen Proyek Konstruksi. Jakarta: Penerbit Graha Ilmu. 
Kasanah, Nur. 2010. Pengadaan Barang dan Jasa di Pemerintahan (Bagian I: Pengertian Umum)., Nurkasanah.blogspot.com. Akses: 18 April 2016

Keputusan Presiden Republik Indonesia Nomor 80 Tahun 2003. Pedoman Pelaksanaan Pengadaan Barang/Jasa Pemerintah Presiden Republik Indonesia. Bandung: Penerbit Citra Umbara.

Peraturan Presiden Republik Indonesia No. 54 Tahun 2010. Pengadaan Barang/Jasa Pemerintah. Bandung: Penerbit Citra Umbara.

Peraturan Presiden Republik Indonesia No. 35 Tahun 2011. Perubahan Pertama Atas Peraturan Presiden No. 54 Tahun 2010 Tentang Pengadaan Barang/Jasa Pemerintah. Bandung: Penerbit Citra Umbara.

Peraturan Presiden Republik Indonesia No. 70 Tahun 2012. Perubahan Kedua Atas Peraturan Presiden No. 54 Tahun 2010 Tentang Pengadaan Barang/Jasa Pemerintah. Bandung: Penerbit Citra Umbara.

Peraturan Presiden Republik Indonesia No. 172 Tahun 2014. Perubahan Ketiga Atas Peraturan Presiden No. 54 Tahun 2010 Tentang Pengadaan Barang/Jasa Pemerintah. Bandung: Penerbit Citra Umbara.

Peraturan Presiden Republik Indonesia No. 04 Tahun 2015. Perubahan Keempat Atas Peraturan Presiden No. 54 Tahun 2010 Tentang Pengadaan Barang/Jasa Pemerintah. Bandung: Penerbit Citra Umbara. 